\section{Activity of Political Science Researchers in Public Debate: Case Study of Poland}

\author{
Anna Sroka \\ University of Warsaw, Poland \\ https://orcid.org/0000-0002-6488-1228
}

Political Preferences

2021, vol. 28: 49-68

journals.us.edu.pl/index.php/PP

Submitted: 15/06/2021

Accepted: 29/06/2021

DOI:10.31261/polpre.2021.28.49-68

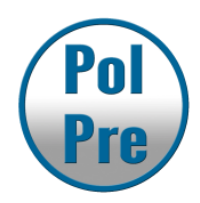

\begin{abstract}
:
This article has several aims. With the help of the original survey data, the article will analyse how Polish political scientists perceive the presence of members of their own scholarly discipline in public debate as desirable and what are their opinions on it. Secondly, the article determines to what extent the political changes initiated in 2015 have affected the general approach to media appearances, and assessments of their content and frequency. Thirdly, an attempt will also be made to determine to what extent the political convictions of political science researchers are correlated with the general assessment of the presence of researchers in public debate, the choice of media in which they are active, and the frequency of their appearances.
\end{abstract}

Keywords: visibility, political science researchers

\title{
Introduction
}

Political science researchers have been active in the media since the beginning of the systemic transformation, although there is no detailed research on their involvement in public debate. Nonetheless, the current situation is quite exceptional. Attempts at a complete reconstruction of the political system after 2015 by the Law and Justice Party in a very short time, led to a very deep polarization of society in Poland, as well as the community of political science researchers. Undoubtedly, as a result of the reforms carried out in Poland, together with the fast way in which they were implemented, in the public consciousness the main source of conflicts became the authorities themselves. According to a CBOS study conducted in 2017, almost half of Poles (47\%) stated that "Polish society is today more divided and in conflict than before the elections in 2015", and only $27 \%$ said that it is "the same". The main reason in the opinion of respondents was "politics, politicians, political views" (34\%); the second reason was the dispute between the two leading parties - Law and Justice and PO - between "government and opposition", "disputes 
between parties" (16\%); and the third (11\%) was given as "failure to observe the Constitution", "capturing of the state", "despotic governments"; the latter was directed at the United Right. Political underpinnings of conflicts encompassed $65 \%$ of all opinions, while only $19 \%$ concerned issues related to material issues and poverty (CBOS, 2017). Therefore, economic inequalities have ceased to be a fundamental factor in social conflicts in Poland (Domański \& DubrowTomescu, 2008), a role that now the political factor has assumed.

Therefore, the aim of this article is, on one hand, first of all, to diagnose the extent to which political scientists in Poland perceive the presence of representatives of their own scholarly discipline in public debate as desirable and their opinions on it. Secondly, to determine to what extent the changes of political system initiated in 2015 have affected the general approach to media appearances, and assessments of their content and frequency. Thirdly, an attempt will also be made to determine to what extent the political convictions of political science researchers are correlated with the general assessment of the presence of researchers in public debate, the choice of media in which they are active, and the frequency of their appearances.

\section{Research model}

Taking the above analyses into account, we may assume that the decision to engage in or withdraw from public debate will result from diverse factors, often related to the political situation in the country. This has its origins in several areas. Firstly, due to the clear division of television and radio into pro-government (public) and opposition (most non-public) media coverage, commenting in mass media can be perceived as an act of support of a specific political option. Secondly, owing to both political and psychological barriers to access to media such as radio, television, and the press, this may generate greater involvement of political science researchers in social media. Thirdly and finally, evaluations of the quality of public debate and discourse with the participation of political scientists after 2015 may be significantly related to the real involvement of respondents.

In the process of study preparation, we formulated the following research questions:

1. Is the presence of political science researchers in public debate desirable for the purpose of improving its quality? 
We consider that irrespective of their own engagement, political science researchers perceive themselves as an integral element of public debate. Their role as observers and commentators will be viewed as a mission and a sort of a duty.

2. How has the presence of political science scholars in public debate been perceived after 2015 in Poland?

As has been mentioned, the social and political situation in Poland since 2015 is a unique one. The sharply defined divisions among the media may constitute a factor in assessments of involvement of political science researchers in public debate. Another distinguishing factor may be the belief in political engagement of commentators.

\section{How might the perception of the political situation after 2015 influence Polish political} scientists in their decision to become involved in the public debate?

We are interested in the motives behind the degree of involvement in public debate after 2015. On one hand, these motives have been presented in an explicitly qualitative manner. On the other, this question is relevant to Question 2. We predict that respondents' own involvement in public debate in Poland after 2015 will be significantly related to their assessment of the general involvement of political science researchers. This relationship may be based on mechanisms of rationalisation. Thus, a politically motivated lack of engagement may be associated with a negative assessment of the quality of engagement by political science researchers. A negative assessment may also be associated with a stronger expression of one's own involvement in social media, which allows one to omit psychological (I do not want to be associated with a political party) and political (lack of access for researchers whose tone is unacceptable to a given medium) barriers.

\section{Method}

The survey was conducted between May and July 2019 among political science researchers in Poland. The targeted sample $(\mathrm{N}=235)$ was used - invitations to participate were extended to scholars employed by universities in Poland who had certified their status as practitioners of the science of politics and administration. The sample encompassed 111 women (47.2\%) and 124 men $(52.8 \%)$. The youngest group, up to and including 29-year-olds, consisted of 21 participants (8.9\%); the age group 30-49 consisted of 53 participants (22.6\%); the largest group was that of 
participants aged 40-49, of which there were 88 people (37.4\%); the age group 50-59 included 36 participants (15.3\%); the oldest age group of 60 and older consisted of 37 participants $(15.7 \%)$. The majority of participants are engaged in research and instruction $(92.3 \%)$, while a small part are employed as teachers (7.7\%). As for their level of academic achievement, the largest group comprises holders of post-doctoral degrees (pol. doctor habilitowany) (41.3\%); slightly fewer are $\mathrm{PhD}$ holders (35.3\%); the next smallest group consists of full professors $(15.3 \%)$; the least numerous are holders of a Master's degree $(8.1 \%)$.

The survey consisted of three parts and a demographic section. The first part concerned the general attitude of respondents towards the participation of political science researchers in public debate. The diagnosis was focused on the general opinion on the need for political science researchers to comment on and explain to the public the processes taking place in the public sphere. In this part we distinguished 3 indicators: 1) continual presence in public debate (indicator based on two questions: "Do you think that political scientists should be present in the public debate on a continual basis to comment on current events?" and "Do you think that political scientists should explain to society the processes taking place in the public sphere?", Crombach's alpha: 0.74); 2) crisis presence in public debate (indicator based on two questions: "Do you think that political scientists should comment on crisis events (e.g. suspicion of breaking the law) in the public sphere?" and "Should political scientists conduct a campaign to monitor the transparency and honesty of public policy undertakings?", Crombach's alpha: 0.64) 3) trustworthiness of public discourse (based on two questions: 'Do you think that objective public debate requires the inclusion of political scientists in the discourse?' and 'Do you think that substantive public debate requires the inclusion of political scientists in the discourse", Crombach's alpha: 0.79). This part also included qualitative descriptions of four type of attitudes of political science researchers, and the respondents were asked to select the option they most closely identified with. These roles were composed based on feedback from an open pilot study conducted prior to this study. Participants could also select the option 'other' and provide their own description of the role.

The second part covered the evaluation of the presence and visibility of political science researchers in public debate after 2015 in Poland. Visibility was assessed in reference to mass media. We were also interested in the perception of political scientists' credibility in particular media and their general competence and objectivity. In this section, we distinguished two 
indicators: 1) visibility of political scientists (average and for particular media outlets); 2) evaluation of political scientists (based on 3 elements: credibility, competence, and objectivity).

The third part diagnosed the presence of the individual respondent in public debate after 2015 in Poland. The questions were aimed at diagnosing the conditions of the self-reported engagement. A qualitative range of activity and passivity determinants was formulated on the basis of a pilot study conducted before the final study. Regarding the declaration of commitment, the diagnosis addressed both the form of the commitment and its directions (type of media and territorial reach).

The survey also consisted of a demographic section with questions about gender, age, position at the workplace, and academic rank/degree.

The individual parts were prepared in accordance with the principle of consistency and commitment. First, the respondents were asked to formulate general attitudes on the need for participation of political science researchers in public space. They were then asked for their opinion on the participation of political science researchers in the debate after 2015. The last part involved a diagnosis of the respondent's participation in public debate after 2015. This formulation of the series of questions aimed at establishing a general attitude towards the issue at hand, and in turn at embedding the respondents' own behaviour in it.

\section{Results}

The first part of the study was general and aimed at diagnosing the general opinion of political science researchers on the involvement of their milieu in public debate. The analysed indicators were verified against variables such as gender, age, and academic degree/rank. The results are presented in relation to statistically significant differences in the Student's t-test, one-way ANOVA variance analysis and post-hoc HSD Tukey test.

Table 1. Average values of indicators of perception of participation by political science researchers in public debate

\begin{tabular}{lcc}
\hline Indicator & Average* & Standard deviation \\
\hline $\begin{array}{l}\text { Desired presence of political science researchers in public debate } \\
\text { Desired presence of political science researchers in public debate }\end{array}$ & 4.12 & .98 \\
$\begin{array}{l}\text { exclusively in crisis situations } \\
\text { Credibility of public discourse with the involvement of political science } \\
\text { researchers }\end{array}$ & 3.92 & 1.13 \\
$*$ 5-point scale & & 1.07 \\
\end{tabular}


Respondents clearly expect political scientists to be active in public debate (Table 1). This indicator is differentiated by age $[\mathrm{F}(4 ; 230)=9.924 ; \mathrm{p}<0.001]$ and academic degree/rank $[\mathrm{F}(3$; 231)=5.998; $p=0.001]$. Significantly stronger expectations of representatives of political science researchers in public debate are demonstrated by their colleagues in the 30-49 age group compared to the youngest group of those aged up to 29 and those older than 50, as well as respondents with a $\mathrm{PhD}$.

At the same time, there is no clear support for the thesis that political scientists should be active only in crisis situations (Table 1). This indicator is marginally differentiated by gender $[\mathrm{t}(233)=2.025 ; \mathrm{p}=0.44]$. Involvement of political scientists only in crisis situations is significantly more often supported by women (1.98 vs 1.8 ).

The credibility of public discourse with the involvement of political scientists is highly rated (Table 1). This indicator is differentiated by respondents' age and academic title/rank held. Participants in the 30-49 age group perceive debate with the participation of political science researchers as significantly more credible in comparison to older respondents in the 50-59 age group, as well as researchers holding a $\mathrm{PhD}$.

\section{Figure 1. Distribution of respondents' answers concerning the expected activity of political science researchers in Poland in public debate (percentages)}
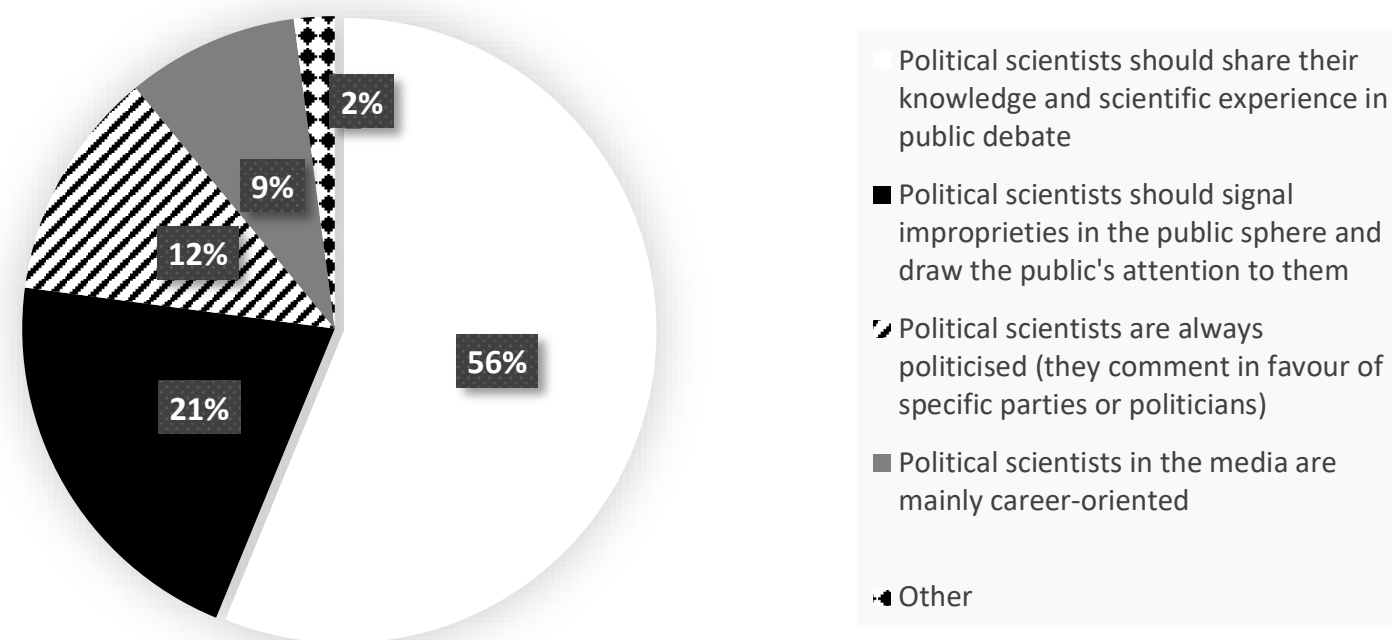
knowledge and scientific experience in public debate

- Political scientists should signal improprieties in the public sphere and draw the public's attention to them

$>$ Political scientists are always politicised (they comment in favour of specific parties or politicians)

- Political scientists in the media are mainly career-oriented

- Other

Seeking to determine the perceived role of political science researchers in Poland, we asked the respondents to respond to several statements. More than half of them (132) feel that political scientists should share their knowledge and scientific experience in public debate. Onefifth (49) are convinced that political scientists should signal improprieties in the public sphere 
and draw the public's attention to them. The least numerous groups are those who believe that political scientists are always politicised (they comment in favour of specific parties or politicians) (28) and those who believe that political scientists in the media are mainly careeroriented (21).

The first part of the study demonstrates that political scientists expect members of their own milieu to participate in public debate. They consider that discourse with the involvement of experts is more credible, and they believe that it should not be limited to crisis situations only. Political scientists believe that the knowledge they possess should be employed appropriately in the public sphere to enhance the quality of discussions and decisions. This experience should also be used to draw the public's attention to improprieties in social and political processes. Importantly, a large number of people have a negative opinion about those political scientists who participate in public debate, considering them politically biased and career-oriented.

The second part of the study concerned the perception of the participation of political scientists in public debate after 2015 in Poland.

\section{Table 2. Average values and standard deviations for indicators of perception of the presence of political scientists in public debate after 2015}

\begin{tabular}{lcc}
\hline Indicator & Average* & Standard deviation \\
\hline Assessment of the presence of political scientists in public debate after 2015 & 3.50 & 1.00 \\
Assessment of the visibility of political scientists in public radio & 3.64 & 1.00 \\
Assessment of the visibility of political scientists in private radio & 3.70 & .88 \\
Assessment of the visibility of political scientists in public television & 3.81 & .97 \\
Assessment of the visibility of political scientists in private television & 3.91 & .79 \\
Assessment of the visibility of political scientists in social media & 3.83 & .98 \\
Assessment of the visibility of political scientists in the press & 3.73 & .94 \\
Assessment of the credibility of political scientists in the media in public & 2.79 & .46 \\
debate after 2015 & & \multirow{2}{*}{1.02} \\
Assessment of the competence of political scientists in the media in public & 3.03 & \\
debate after 2015 & & \multirow{2}{*}{1.05} \\
Assessment of the objectivity of political scientists in the media in public & 2.67 & \\
debate after 2015 & & \\
\hline
\end{tabular}

*5-point scale

Respondents rate the presence of political scientists in public discourse after 2015 above average (Table 2). Their visibility in particular media was perceived as follows: private television (3.91); social media (3.83); public television (3.80); press (3.72); private radio (3.69); public radio (3.64). Media visibility is not differentiated by gender or rank/title. Significant age 
differences were observed in respect of visibility in private media and television and social media. The youngest political scientists and those aged 40-49 are more visible.

Despite the visibility of political scientists in the media, their competences were assessed at an average level, while their credibility and objectivity were judged even worse (Table 2). This assessment is not differentiated by gender or academic rank/title. On the other hand, the age of respondents is distinct both in the case of competences attributed to political scientists in the media and objectivity. The most critical groups are people aged 50-59.

\section{Figure 2. Distribution of responses by political science researchers concerning engagement of political scientists in public discourse in Poland after 2015 (percentages)}

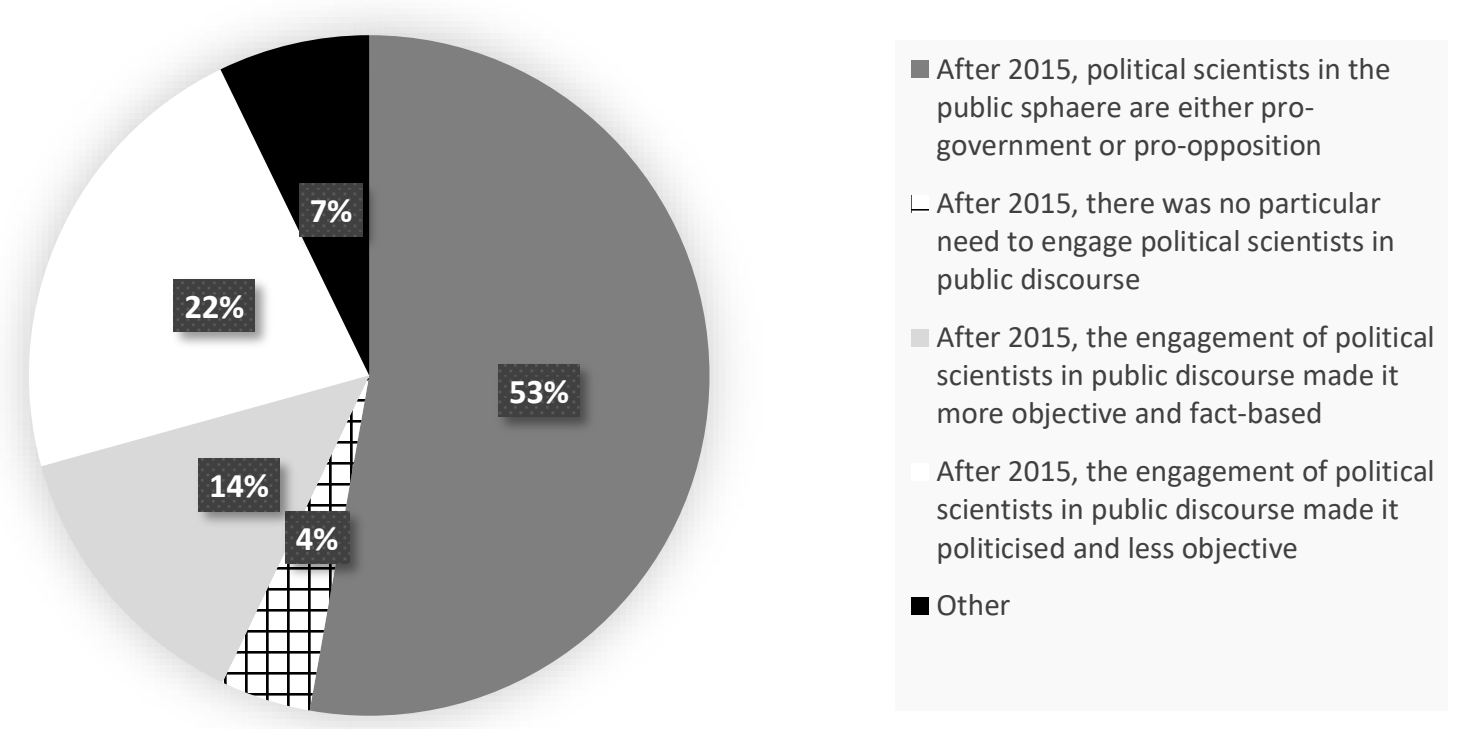

More than half of the respondents are of the opinion that after 2015 political scientists in the public sphere (Figure 2) are either pro-government or pro-opposition (124). Every fifth respondent (52) notes that public discourse has lost its objectivity and apoliticism after 2015 due to the involvement of political scientists. To sum up, political scientists were quite visible in the public discourse conducted in the media after 2015. However, evaluation of the quality of their activity was poor. A significant portion of respondents attribute politicisation to them and note that the discourse cheapened since 2015.

The third part of the survey was aimed at diagnosing the respondents' own activity in public debate. 


\title{
Figure 3. Distribution of responses of political science researchers to the reasons for their inactivity in public debate after 2015 in Poland (percentages)
}

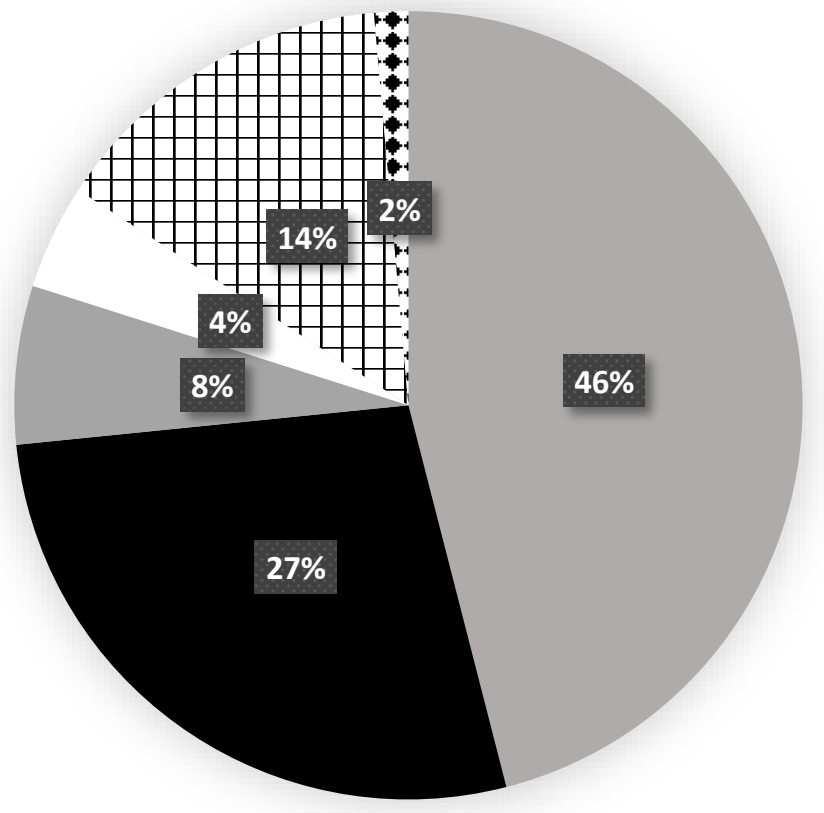

\author{
I don't want to be associated with any \\ particular political party \\ - In my opinion, a scholar's job is \\ something else (scientific \\ work/publishing, research projects) \\ - I don't feel competent as a \\ commentator \\ I don't have time \\ T I don't have the chance because the \\ same people keep getting asked to \\ appear as commentators \\ . Other
}

Nearly $60 \%$ of respondents declared that they did not participate in public debate (139). Nearly half of the respondents declared their reluctance to be associated with a political party as the main reason (Figure 3) for inactivity (64). Nearly one in three believe that the tasks scholars should perform are different, mostly related to publishing and research activity (38). A relatively significant percentage of respondents said that there was no opportunity, because the same people keep appearing as commentators (20). Interestingly, passivity is significantly related to the perception of the quality of community involvement after 2015 - people who assess the competence of commentators after $2015[\chi 2(4 ; 235)=22.673 ; p<0.001]$ and their objectivism $[\chi 2(4 ; 235)=33.907 ; \mathrm{p}<0.001]$ poorly are more likely to remain passive. 
Table 3. Reasons for declared passivity versus convictions on the role of political scientists in public debate

\begin{tabular}{|c|c|c|c|c|c|c|c|}
\hline & & $\begin{array}{l}\text { I don't want } \\
\text { to be } \\
\text { associated } \\
\text { with any } \\
\text { particular } \\
\text { political party }\end{array}$ & $\begin{array}{l}\text { In my opinion, a } \\
\text { scholar's job is } \\
\text { something else } \\
\text { (scientific work } \\
\text { - publishing, } \\
\text { research } \\
\text { projects) }\end{array}$ & $\begin{array}{l}\text { I don't feel } \\
\text { competent as } \\
\text { a } \\
\text { commentator }\end{array}$ & $\begin{array}{l}\text { I don't have } \\
\text { time }\end{array}$ & $\begin{array}{l}\text { I don't have } \\
\text { the chance } \\
\text { because the } \\
\text { same people } \\
\text { keep getting } \\
\text { asked to } \\
\text { appear as } \\
\text { commentators }\end{array}$ & other \\
\hline $\begin{array}{l}\text { Political } \\
\text { scientists should } \\
\text { share their } \\
\text { knowledge and } \\
\text { scientific } \\
\text { experience in } \\
\text { public debate }\end{array}$ & $\begin{array}{l}\mathrm{N} \\
\%\end{array}$ & $\begin{array}{c}30 \\
46.9\end{array}$ & $\begin{array}{c}4 \\
10.5\end{array}$ & $\begin{array}{c}5 \\
55.6\end{array}$ & $\begin{array}{c}6 \\
100.0\end{array}$ & $\begin{array}{c}15 \\
75.0\end{array}$ & $\begin{array}{c}2 \\
100,0\end{array}$ \\
\hline $\begin{array}{l}\text { Political } \\
\text { scientists should } \\
\text { signal } \\
\text { improprieties in } \\
\text { the public sphere } \\
\text { and draw the } \\
\text { public's attention } \\
\text { to them }\end{array}$ & $\begin{array}{l}\mathrm{N} \\
\%\end{array}$ & $\begin{array}{c}20 \\
31.3\end{array}$ & $\begin{array}{c}7 \\
18.4\end{array}$ & $\begin{array}{c}3 \\
33.3\end{array}$ & $\begin{array}{c}0 \\
0.0\end{array}$ & $\begin{array}{c}5 \\
25.0\end{array}$ & $\begin{array}{c}0 \\
0,0\end{array}$ \\
\hline $\begin{array}{l}\text { Political } \\
\text { scientists are } \\
\text { always } \\
\text { politicised (they } \\
\text { comment in } \\
\text { favour of } \\
\text { specific parties } \\
\text { or politicians) }\end{array}$ & $\begin{array}{l}\mathrm{N} \\
\%\end{array}$ & $\begin{array}{c}14 \\
21.9\end{array}$ & $\begin{array}{c}10 \\
26.3\end{array}$ & $\begin{array}{c}0 \\
0.0\end{array}$ & $\begin{array}{c}0 \\
0.0\end{array}$ & $\begin{array}{c}0 \\
0.0\end{array}$ & $\begin{array}{c}0 \\
0.0\end{array}$ \\
\hline $\begin{array}{l}\text { Political } \\
\text { scientists in the } \\
\text { media are } \\
\text { mainly career- } \\
\text { oriented }\end{array}$ & $\begin{array}{l}\mathrm{N} \\
\%\end{array}$ & $\begin{array}{c}0 \\
0.0\end{array}$ & $\begin{array}{c}12 \\
31.6\end{array}$ & $\begin{array}{c}1 \\
11.1\end{array}$ & $\begin{array}{c}0 \\
0.0\end{array}$ & $\begin{array}{c}0 \\
0.0\end{array}$ & $\begin{array}{c}0 \\
0.0\end{array}$ \\
\hline Other & $\begin{array}{l}\mathrm{N} \\
\%\end{array}$ & $\begin{array}{c}0 \\
0.0\end{array}$ & $\begin{array}{c}5 \\
13.2 \\
\end{array}$ & $\begin{array}{c}0 \\
0.0\end{array}$ & $\begin{array}{c}0 \\
0.0\end{array}$ & $\begin{array}{c}0 \\
0.0\end{array}$ & $\begin{array}{c}0 \\
0.0\end{array}$ \\
\hline Total & $\begin{array}{l}\mathrm{N} \\
\%\end{array}$ & $\begin{array}{c}64 \\
100.0\end{array}$ & $\begin{array}{c}38 \\
100.0\end{array}$ & $\begin{array}{c}9 \\
100.0\end{array}$ & $\begin{array}{c}6 \\
100.0\end{array}$ & $\begin{array}{c}20 \\
100.0\end{array}$ & $\begin{array}{c}2 \\
100.0\end{array}$ \\
\hline
\end{tabular}

It is also interesting to see the association of the reasons for declared passivity with the convictions of political science researchers about the general role of political scientists in public debate (Table 3). The majority of political science researchers who declared that they do not want to be associated with any political party also declared that political scientists should be present in the public debate, sharing their knowledge and experience, and signalling irregularities. Only 
every fifth passive political science researcher consistently claimed that political scientists are always associated with some political party. This could be a sign of the activation of a mechanism for rationalizing the non-involvement of political scientists, which requires further research. Among those of the opinion that the tasks of political science researchers are more closely related to scientific work, a significant portion feels that the activity of researchers in the media is career oriented.

\section{Figure 4: Distribution of declarations of political science researchers on the form of their participation in public debate (percentages)}
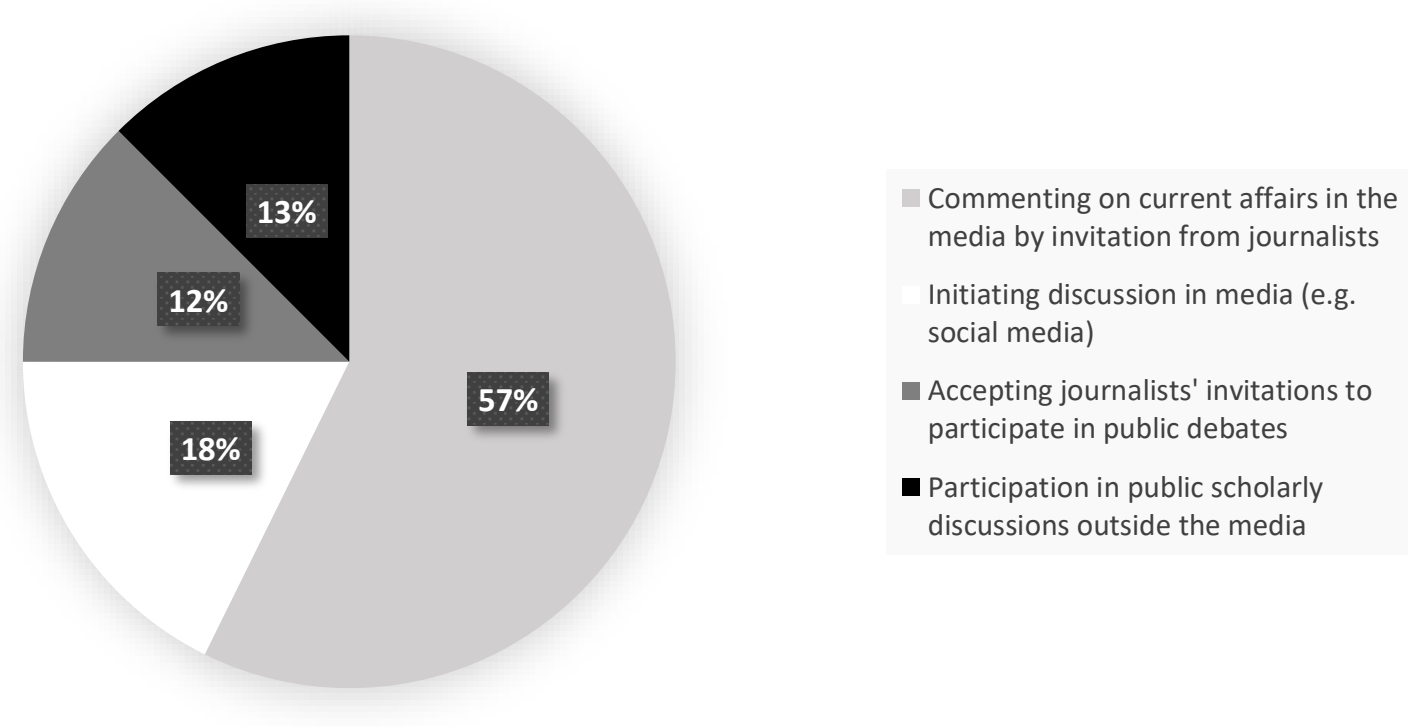

The activity of political scientists most often takes the form of responses to invitations by journalists (55) (Figure 4). Almost every fifth person initiates discussions in the media (e.g. social media) (17).

The level of declared involvement by researchers in various media is low. On a five-point scale, it is highest in social media (2.67), private television (2.27), private radio (2.25), press (2.20), public radio (2.01) and public television (1.59). In the majority of media, men present themselves as significantly more active - exceptions are social media and public radio where no significant gender differences were noted. Age, on the other hand, differentiates activity only in social media. People under the age of 39 are significantly more likely to use social media than political science researchers over the age of 40. Academic rank/title does not differentiate involvement in particular media types. 
The declared engagement is the highest at the national level (2.74), slightly lower at the local (2.39) and regional level (2.29), and weakest at the international level (1.70). At almost all levels of engagement men declare significantly higher activity. The exception is the local level where no gender differences are noted. Age significantly differentiates declarative engagement at local and regional level. At the local level, significantly higher activity is declared by the youngest political scientists and those in the 40-49 age group. At the regional level, on the other hand, political scientists in the 30-39 age bracket exhibit the lowest activity. The remaining groups constitute a homogeneous set. The possessed academic rank differentiates activity only at the local level. Masters' degree holders demonstrate significantly the highest engagement among other science degrees.

\section{Figure 5. Distribution of respondents' answers on the reasons for their involvement in public debate (percentages)}

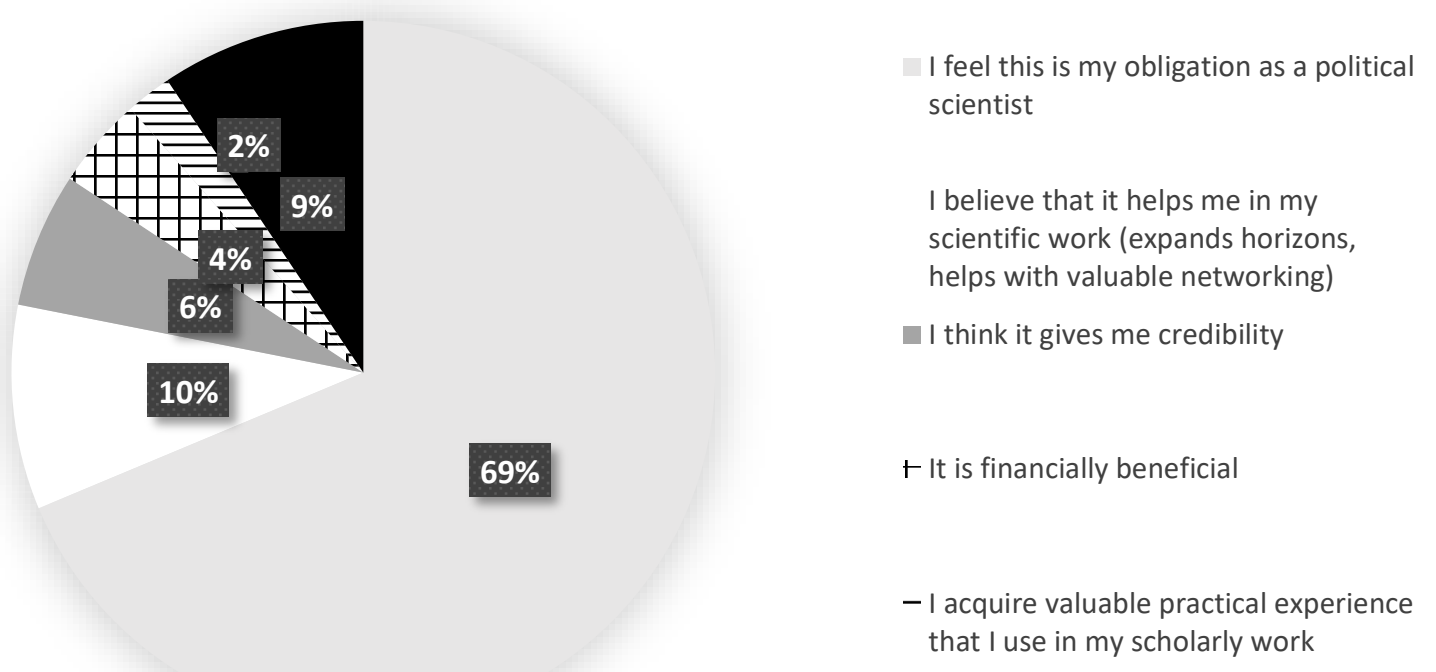

Giving reasons for their activity in the public space, the vast majority of political scientists consider such involvement their duty (66). Nearly every tenth respondent (9) considers such activity as helpful in academic work or as a form of creating an image (9).

In conclusion, the majority of political science researchers do not participate in public debate. The prevailing reason is based on the conviction that political scientists involved in public discourse are politicized. A significant part also believes that political scientists' duties are in another area, which should not be connected with public space. Among the people who are involved, activity initiated by journalists prevails - political scientists willingly accept their 
invitation to comment on current events. The reactivity of political scientists is significantly stronger than their initiative. Declarative engagement is relatively weak. The range of engagement is also low, especially at the international level.

\section{Discussion}

In the course of the research, three research questions were posed. The first one was aimed at a general diagnosis of the opinion of political scientists as to the participation of their milieu in public debate. The study confirmed our hypothesis that political scientists are desired in public discourse. The role of political scientists and commentators is perceived as a mission respondents are of the opinion that the experience and knowledge of political science researchers should be used to improve the quality of public debate. Interestingly, this attitude is most evident among people aged 30-49. One may think that these are researchers aware of their place in the public space. It can be assumed that people in this age group should also be much more often stabilised financially and in their private life, hence energy and involvement find its outlet in the professional sphere. Academic rank generally corresponds with age - more often these are people with a doctoral degree, but it can be assumed that this is a natural consequence of the stages of professional development in Poland (usually the doctoral degree is obtained at the age of about 30, while the post-doctoral degree at about 45, although the tendency is for the latter to decline).

The second research question was aimed at diagnosing the attitudes of political science researchers towards the participation of their milieu in public debate after 2015 in Poland. The results show unequivocally that the political science community is noticeable in the media after 2015, but the assessment of this involvement is not positive. Credibility, competence and objectivity were assessed no better than average at best. The responses also indicate that the activity of political science researchers in the media is perceived as politicised and it lowers the quality of public discourse. Interestingly, the youngest survey participants up to 29 and those aged 40-49 perceive political scientists active in the media better than older researches aged between 50-59, who are the most critical observers.

The third research question was aimed at diagnosing the determinants and direction of individual involvement of respondents in public debate after 2015. The perception of such activity as naturally combined with support for specific political parties was given as the main motive for passivity. A large group of people decisively separates scientific work and practical 
involvement in public space, stating that the tasks of scholars are research, publications and projects. Importantly, those who declare passivity offer a poorer assessment of the competence and objectivity of commentators after 2015. This may be related to the radicalisation of discourse in the media about reforms, both public and private, and their growing political polarisation. This may be also both a mechanism to rationalise their passivity and its direct cause. The activity of researchers usually takes a reactive form - accepting the invitation of journalists. The declared engagement is quite weak - the highest in social media, the weakest in public television. Men are more active in most media, while in social media younger people under 39 are more active. Researchers more often declare involvement at the local and regional level, where the youngest researchers are more active, and researchers in the 40-49 age group The weakest activity is presented by people aged 30-39 at the local and regional level.

The above study was inspired by the PROSEPS programme (Vicentini et al., 2019), within the framework of COST Action 15210, whose authors serve as representatives of Poland in the Management Committee. The discussions conducted within the programme's framework clearly demonstrated that the role of political science researchers in public debate is perceived in various ways, and has a significant link with the cultural, social, and political context of particular countries. The relations between researchers and representatives of the media are similar. In consequence, this means that the role of political science researchers is also different in scenarios involving coping with crisis situations in various countries and their involvement in public debate. Studies conducted in Poland, which results are presented above, confirm the trends diagnosed in a European study in respect of our country. Interestingly, set against the backdrop of other European countries, Polish researchers offer similar opinions, which are nevertheless more carefully and conditionally formulated. For example, in comparison to the PROSEPS study in Poland, significantly fewer political science researchers declare participation in public debate ( $40.9 \%$ vs $57.5 \%)$. Among active Polish researchers, the majority agreed that such participation is a part of their role as scientists. However, this is a far smaller percentage than in the general European study (68.7\% vs 95.6\%). In the European study, 9 out of 10 researchers agreed that scientists should be involved in public debate, as this is a part of their social role (91.6\%). This is also a popular opinion identified in the Polish study, but far more conditional here. At the national level - similarly to the European - political science researchers are visible in the public debate to a similar extent. However, in Poland they are mainly perceived as lowering the level of 
public discourse, while in Europe as competent commentators, but without any real impact on the course of events.

Analysing the Polish context of the study, a caution in the formation of unequivocal judgements can be found in the political, social, and media context that Poland finds itself in. Here we should note the specificity of the Polish political science researcher community. The progressing political polarization that has accelerated since 2015 has also impacted this milieu. Furthermore, post-communist divisions remain. Some of them continue to be perceived through the lens of their affiliation with the old communist system, while there are also others aged 35-45, who still remember the communist system, but went through the phases of their career in democratic Poland. The rhetoric of the present ruling party includes numerous references to the divide between former communists and support of "free and independent Poland." This rhetoric impacts the progressing polarization among Polish political scientists, and also influences both attitudes towards the changes initiated in 2015 and the selection of media in which political science researchers choose to appear in.

Taking the above into account, it is difficult at present to indicate a clear role played by political science researchers in the public debate in Poland. Firstly, there is a large group of individuals who seek to avoid engaging in public debate, in the belief that their tasks are primarily of a strictly scientific nature (studies, conferences, etc.). Secondly, there are individuals who remain passive, justifying their lack of engagement by their negative perception of activity by political science researchers in public debate (poor assessment of their competences, associating them with putting their career before everything else, perception of their activity as politicised). Thirdly, there are political science researchers (albeit a minority) who actively share their experience and knowledge in public debate, considering it their mission and an integral element of their professional work.

\section{Acknowledgements}

I would like to thank Professor Agnieszka Turska-Kawa from the University of Silesia, with whom I conducted the research conducted as part of the PROSEPS programme, within the framework of COST Action 15210. 


\section{Anna Sroka}

\section{References:}

CBOS (2017). O polityce, która nie buduje wspólnoty (Komunikat z Badań nr 144/2015). Centrum Badania Opinii Społecznej.

Domański, H., \& Dubrow-Tomescu, I. (2008). Postrzeganie konfliktów, 1988-2003 [Perception of the conflicts, 1988-2003]. In A. Rychard (Ed.) Strukturalne podstawy demokracji [Structural foundations of democracy] (pp. 4782). IFIS PAN.

Vicentini, G., Real Dato, J., Verzichelli, L., \& Andreadis, I. (2019). Social Visibility and Impact of European Political Scientists. PROSEPS WG3 2019 Report.

\section{Appendix}

Table 1. Results post-doc HSD Tukey test - political scientists' expectations to be active in public debate (by age)

\begin{tabular}{c|ccccc}
\hline & Up to $29(3.57)$ & $30-39(4.43)$ & $40-49(4.17)$ & $50-59(3.19)$ & $>60(3.72)$ \\
\cline { 2 - 6 } Up to 29 (3.57) & $\mathrm{X}$ & $\begin{array}{c}\mathrm{I}-\mathrm{J}=0.862 \\
\mathrm{p}=0.011\end{array}$ & - & - & - \\
$30-39(4.43)$ & $\begin{array}{c}\mathrm{I}-\mathrm{J}=0.862 \\
\mathrm{p}=0.011\end{array}$ & $\mathrm{X}$ & - & $\begin{array}{c}\mathrm{I}-\mathrm{J}=1.24 \\
\mathrm{p}<0,001\end{array}$ & $\begin{array}{c}\mathrm{I}-\mathrm{J}=0.704 \\
\mathrm{p}=0.014\end{array}$ \\
$40-49(4.17)$ & - & - & $\mathrm{X}$ & $\begin{array}{c}\mathrm{I}-\mathrm{J}=0.976 \\
\mathrm{p}<0.001\end{array}$ & - \\
$50-59(3.19)$ & - & $\begin{array}{c}\mathrm{I}-\mathrm{J}=1.24 \\
\mathrm{p}<0.001\end{array}$ & $\begin{array}{c}\mathrm{I}-\mathrm{J}=0.976 \\
\mathrm{p}<0.001\end{array}$ & $\mathrm{X}$ & - \\
$>60(3.72)$ & - & $\begin{array}{c}\mathrm{I}-\mathrm{J}=0.704 \\
\mathrm{p}=0.014\end{array}$ & - & - & $\mathrm{X}$ \\
\hline
\end{tabular}

Table 2. Results post-doc HSD Tukey test - political scientists' expectations to be active in public debate (by degree)

\begin{tabular}{c|cccc|}
\hline \multicolumn{1}{c}{} & MA (3.94) & PhD (4.34) & Post-doc (3.72) & Professor (3.69) \\
\cline { 2 - 5 } MA (3.94) & $\mathrm{X}$ & - & - & - \\
$\operatorname{PhD}(4.34)$ & - & $\mathrm{X}$ & $\mathrm{I}-\mathrm{J}=0.627$ & $\mathrm{I}-\mathrm{J}=0.654$ \\
& - & $\mathrm{I}-\mathrm{J}=0.627$ & $\mathrm{p}=0.001$ & $\mathrm{p}=0.013$ \\
Post-doc (3.72) & - & $\mathrm{p}=0.001$ & $\mathrm{X}$ & - \\
Professor (3.69) & - & $\mathrm{I}-\mathrm{J}=0.654$ & - & $\mathrm{X}$ \\
\hline
\end{tabular}


Table 3. Results post-doc HSD Tukey test - credibility of public discourse with the involvement of political scientists is highly rated (by age)

\begin{tabular}{c|ccccc}
\hline & Up to $29(3.78)$ & $30-39(4.43)$ & $40-49(4.00)$ & $50-59(3.37)$ & $>60(3.77)$ \\
\cline { 2 - 6 } & $\mathrm{X}$ & - & - & - & - \\
$30-39(4.43)$ & - & $X$ & - & $\begin{array}{c}\mathrm{I}-\mathrm{J}=0.936 \\
\mathrm{p}<0.001\end{array}$ & - \\
$40-49(4.00)$ & - & - & $\mathrm{I}-\mathrm{J}=0.625$ & - \\
$50-59(3.37)$ & - & $\mathrm{I}-\mathrm{J}=0.936$ & $\mathrm{I}-\mathrm{J}=0.625$ & $\mathrm{p}=0.023$ & - \\
& & $\mathrm{p}<0,001$ & $\mathrm{p}=0.023$ & $X$ & $X$ \\
\hline
\end{tabular}

Table 4. Results post-doc HSD Tukey test - credibility of public discourse with the involvement of political scientists is highly rated (by degree)

\begin{tabular}{c|cccc}
\hline \multirow{2}{*}{ MA $(3,80)$} & MA (3.80) & $\operatorname{PhD}(4.25)$ & Post-doc (3.72) & Professor (3.77) \\
\cline { 2 - 5 } & $\mathrm{X}$ & - & - & - \\
$\operatorname{PhD}(4,25)$ & - & $\mathrm{X}$ & $\mathrm{I}-\mathrm{J}=0.531$ & $\mathrm{I}-\mathrm{J}=0.517$ \\
& & $\mathrm{p}=0.005$ & $\mathrm{p}=0.009$ \\
Post-doc $(3,72)$ & - & $\mathrm{I}-\mathrm{J}=0.531$ & $\mathrm{X}$ & - \\
Professor $(3,77)$ & - & $\mathrm{p}=0.005$ & - & $\mathrm{X}$ \\
\hline
\end{tabular}

Table 5. Results post-doc HSD Tukey test - visibility of political science researchers in private radio (by age)

\begin{tabular}{|c|c|c|c|c|c|}
\hline & Up to $29(4.14)$ & $30-39(3.36)$ & $40-49(3.92)$ & $50-59(3.61)$ & $>60(3.48)$ \\
\hline Up to $29(4,14)$ & - & $\begin{array}{c}\mathrm{I}-\mathrm{J}=0.784 \\
\mathrm{p}=0.004\end{array}$ & $\mathrm{X}$ & $\mathrm{X}$ & $\begin{array}{c}\mathrm{I}-\mathrm{J}=0.656 \\
\mathrm{p}=0.02\end{array}$ \\
\hline 30-39 (3,36) & $\begin{array}{c}\mathrm{I}-\mathrm{J}=0.784 \\
\mathrm{p}=0.004\end{array}$ & - & $\begin{array}{c}\mathrm{I}-\mathrm{J}=0.561 \\
\mathrm{p}=0.002\end{array}$ & $\mathrm{X}$ & $X$ \\
\hline $40-49(3,92)$ & $\mathrm{X}$ & $\begin{array}{c}\mathrm{I}-\mathrm{J}=0.561 \\
\mathrm{p}=0.002\end{array}$ & - & $\mathrm{X}$ & $X$ \\
\hline $50-59(3,61)$ & $\mathrm{X}$ & $\mathrm{X}$ & $\mathrm{X}$ & - & $\mathrm{X}$ \\
\hline$>60(3,48)$ & $\begin{array}{c}\mathrm{I}-\mathrm{J}=0.656 \\
\mathrm{p}=0.02\end{array}$ & $X$ & $\mathrm{X}$ & $\mathrm{X}$ & - \\
\hline
\end{tabular}

Table 6. Results post-doc HSD Tukey test - visibility of political science researchers in private television (by age)

\begin{tabular}{|c|c|c|c|c|c|}
\hline & Up to $29(4.14)$ & $30-39(3.70)$ & $40-49(4.16)$ & $50-59(3.55)$ & $>60(3.84)$ \\
\hline Up to $29(4.14)$ & - & $\mathrm{X}$ & $\mathrm{X}$ & $\begin{array}{c}\mathrm{I}-\mathrm{J}=0.59 \\
\mathrm{p}=0.04\end{array}$ & $\mathrm{X}$ \\
\hline $30-39$ (3.70) & $\mathrm{X}$ & - & $\begin{array}{l}\mathrm{I}-\mathrm{J}=0.46 \\
\mathrm{p}=0.005\end{array}$ & $\mathrm{X}$ & $\mathrm{X}$ \\
\hline $40-49$ (4.16) & $X$ & $\begin{array}{l}\mathrm{I}-\mathrm{J}=0.46 \\
\mathrm{p}=0.005\end{array}$ & - & $\begin{array}{l}\mathrm{I}-\mathrm{J}=0.60 \\
\mathrm{p}=0.001\end{array}$ & $\mathrm{X}$ \\
\hline $50-59$ (3.55) & $\begin{array}{c}\mathrm{I}-\mathrm{J}=0.59 \\
\mathrm{p}=0.04\end{array}$ & $X$ & $\begin{array}{l}\mathrm{I}-\mathrm{J}=0.60 \\
\mathrm{p}=0.001\end{array}$ & - & X \\
\hline$>60(3.84)$ & $\mathrm{X}$ & $\mathrm{X}$ & $X$ & $X$ & - \\
\hline
\end{tabular}


Table 7. Results post-doc HSD Tukey test - visibility of political science researchers in social media (by age)

\begin{tabular}{|c|c|c|c|c|c|}
\hline & Up to 29 (4.09) & $30-39(3.64)$ & $40-49(4.06)$ & $50-59(3.80)$ & $>60(3.43)$ \\
\hline Up to 29 (4.09) & $X$ & - & - & - & $\begin{array}{c}\mathrm{I}-\mathrm{J}=0.062 \\
\mathrm{p}=0.005\end{array}$ \\
\hline $30-39(3.64)$ & - & $\mathrm{X}$ & - & - & - \\
\hline $40-49(4.06)$ & - & - & $\mathrm{X}$ & - & $\begin{array}{l}I-J=0.64 \\
p=0.008\end{array}$ \\
\hline $50-59(3.80)$ & - & - & - & $\mathrm{X}$ & - \\
\hline$>60(3.43)$ & $\begin{array}{c}\mathrm{I}-\mathrm{J}=0.062 \\
\mathrm{p}=0.005\end{array}$ & - & $\begin{array}{l}\mathrm{I}-\mathrm{J}=0.64 \\
\mathrm{p}=0.008\end{array}$ & - & $\mathrm{X}$ \\
\hline
\end{tabular}

Table 8. Results post-doc HSD Tukey test - assessment of the competence of political scientists in the media in public debate after 2015 (by age)

\begin{tabular}{|c|c|c|c|c|c|}
\hline & Up to $29(2.57)$ & $30-39(3.21)$ & $40-49(3.19)$ & $50-59(2.52)$ & $>60(3.13)$ \\
\hline Up to $29(2.57)$ & $\mathrm{X}$ & - & - & - & - \\
\hline $30-39(3.21)$ & - & $X$ & - & $\begin{array}{c}\mathrm{I}-\mathrm{J}=0.067 \\
\mathrm{p}=0.015\end{array}$ & - \\
\hline $40-49(3.19)$ & - & - & $X$ & $\begin{array}{l}\mathrm{I}-\mathrm{J}=0.66 \\
\mathrm{p}=0.008\end{array}$ & - \\
\hline $50-59(2.52)$ & - & $\begin{array}{c}\mathrm{I}-\mathrm{J}=0.067 \\
\mathrm{p}=0.015\end{array}$ & $\begin{array}{l}I-J=0.66 \\
p=0.008\end{array}$ & $X$ & - \\
\hline$>60(3.13)$ & - & - & - & - & $\mathrm{X}$ \\
\hline
\end{tabular}

Table 9. Results post-doc HSD Tukey test - Assessment of the objectivity of political scientists in the media in public debate after 2015 (by age)

\begin{tabular}{c|ccccc}
\hline & Up to $29(2.48)$ & $30-39(2.87)$ & $40-49(2.80)$ & $50-59(2.22)$ & $>60(2.65)$ \\
\cline { 2 - 5 } Up to 29 (2.48) & $\mathrm{X}$ & - & - & - & - \\
$30-39(2.87)$ & - & $\mathrm{X}$ & - & $\mathrm{I}-\mathrm{J}=0.65$ & $\mathrm{p}=0.034$ \\
$40-49(2.80)$ & - & - & $\mathrm{I}-\mathrm{J}=0.57$ & $\mathrm{p}=0.044$ \\
$50-59(2.22)$ & - & $\mathrm{I}-\mathrm{J}=0.65$ & $\mathrm{I}-\mathrm{J}=0.57$ & $\mathrm{X}$ & - \\
$\mathrm{p}=0.034$ & $\mathrm{p}=0.044$ & - & $\mathrm{X}$ \\
\hline
\end{tabular}

Table 10. Results t-Student test - declared involvement in various media (by gender)

\begin{tabular}{|c|c|c|c|}
\hline & Test $t$ result & Women & Men \\
\hline Private radio & $\begin{array}{c}t(89)=-3.587 \\
p=0.001\end{array}$ & 1.73 & 2.55 \\
\hline Private television & $\begin{array}{c}\mathrm{t}(88,944)=-6.128 \\
\mathrm{p}<0.001\end{array}$ & 1.45 & 1.74 \\
\hline Public television & $\begin{array}{c}\mathrm{t}(88,369)=-3.493 \\
\mathrm{p}=0.004\end{array}$ & 1.18 & 1.81 \\
\hline Press & $\begin{array}{c}\mathrm{t}(85,075)=-4.674 \\
\mathrm{p}=0.002\end{array}$ & 1.57 & 2.57 \\
\hline
\end{tabular}


Table 11. Results post-doc HSD Tukey test - visibility of science researchers in social media (by age)

\begin{tabular}{|c|c|c|c|c|c|}
\hline & Up to 29 (3.71) & $30-39(3.93)$ & $40-49(2.02)$ & $50-59(2.80)$ & $>60(2.08)$ \\
\hline Up to $29(3.71)$ & $\mathrm{X}$ & - & $\begin{array}{l}\mathrm{I}-\mathrm{J}=1.91 \\
\mathrm{p}<0.001\end{array}$ & $\begin{array}{l}\mathrm{I}-\mathrm{J}=1.48 \\
\mathrm{p}=0.017\end{array}$ & - \\
\hline $30-39(3.93)$ & - & $\mathrm{X}$ & $\begin{array}{l}\mathrm{I}-\mathrm{J}=1.91 \\
\mathrm{p}<0.001\end{array}$ & - & $\begin{array}{l}\mathrm{I}-\mathrm{J}=1,85 \\
\mathrm{p}=0.002\end{array}$ \\
\hline $40-49$ (2.02) & $\begin{array}{l}\mathrm{I}-\mathrm{J}=1.91 \\
\mathrm{p}<0.001\end{array}$ & $\begin{array}{l}\mathrm{I}-\mathrm{J}=1.91 \\
\mathrm{p}<0.001\end{array}$ & $\mathrm{X}$ & - & - \\
\hline $50-59(2.80)$ & $\begin{array}{l}\mathrm{I}-\mathrm{J}=1.48 \\
\mathrm{p}=0.017\end{array}$ & - & - & $\mathrm{X}$ & - \\
\hline$>60(2.08)$ & - & $\begin{array}{l}\mathrm{I}-\mathrm{J}=1.85 \\
\mathrm{p}=0.002\end{array}$ & - & - & $\mathrm{X}$ \\
\hline
\end{tabular}

Table 12. Results t-Student test - declared involvement in various level (by gender)

\begin{tabular}{|c|c|c|c|}
\hline & Test $t$ result & Women & Men \\
\hline Regional level & $\begin{array}{c}t(89)=-2.893 \\
p=0.005\end{array}$ & 1.84 & 2.55 \\
\hline National level & $\begin{array}{c}\mathrm{t}(89)=-3.820 \\
\mathrm{p}<0.001\end{array}$ & 2.15 & 3.07 \\
\hline International level & $\begin{array}{c}\mathrm{t}(89)=-2.159 \\
\mathrm{p}=0.034\end{array}$ & 1.42 & 1.86 \\
\hline
\end{tabular}

Table 13. Results post-doc HSD Tukey test -declared engagement on the local level (by age)

\begin{tabular}{|c|c|c|c|c|c|}
\hline & Up to $29(3.86)$ & $30-39(1.13)$ & $40-49(3.42)$ & $50-59(3.06)$ & $>60(2.08)$ \\
\hline Up to $29(3.86)$ & $\mathrm{X}$ & $\begin{array}{l}I-J=2.72 \\
p<0.001\end{array}$ & $\begin{array}{l}\mathrm{I}-\mathrm{J}=1.40 \\
\mathrm{p}=0.039\end{array}$ & - & $\begin{array}{c}\mathrm{I}-\mathrm{J}=1.77 \\
\mathrm{p}=0.02\end{array}$ \\
\hline $30-39(1.13)$ & $\begin{array}{l}\mathrm{I}-\mathrm{J}=2.72 \\
\mathrm{p}<0.001\end{array}$ & $\mathrm{X}$ & - & $\begin{array}{l}\mathrm{I}-\mathrm{J}=1.93 \\
\mathrm{p}<0.001\end{array}$ & - \\
\hline $40-49(3.42)$ & $\begin{array}{l}\mathrm{I}-\mathrm{J}=1.40 \\
\mathrm{p}=0.039\end{array}$ & - & $X$ & - & - \\
\hline $50-59(3.06)$ & - & $\begin{array}{l}\mathrm{I}-\mathrm{J}=1.93 \\
\mathrm{p}<0.001\end{array}$ & - & $\mathrm{X}$ & - \\
\hline$>60(2.08)$ & $\begin{array}{c}\mathrm{I}-\mathrm{J}=1.77 \\
\mathrm{p}=0.02\end{array}$ & - & - & - & $X$ \\
\hline
\end{tabular}

Table 14. Results post-doc HSD Tukey test -declared engagement on the regional level (by age)

\begin{tabular}{|c|c|c|c|c|c|}
\hline & Up to $29(3.00)$ & $30-39(1.13)$ & $40-49(2.45)$ & $50-59(2.60)$ & $>60(1.44)$ \\
\hline Up to $29(3.00)$ & $\mathrm{X}$ & $\begin{array}{l}\mathrm{I}-\mathrm{J}=1.87 \\
\mathrm{p}=0.002\end{array}$ & - & - & - \\
\hline $30-39(1.13)$ & $\begin{array}{l}\mathrm{I}-\mathrm{J}=1.87 \\
\mathrm{p}=0.002\end{array}$ & $\mathrm{X}$ & $\begin{array}{l}\mathrm{I}-\mathrm{J}=1.32 \\
\mathrm{p}=0.001\end{array}$ & $\begin{array}{l}\mathrm{I}-\mathrm{J}=1.47 \\
\mathrm{p}=0.002\end{array}$ & $\begin{array}{l}\mathrm{I}-\mathrm{J}=1.28 \\
\mathrm{p}=0.018\end{array}$ \\
\hline $40-49(2.45)$ & - & $\begin{array}{l}\mathrm{I}-\mathrm{J}=1.32 \\
\mathrm{p}=0.001\end{array}$ & $\mathrm{X}$ & - & - \\
\hline $50-59(2.60)$ & - & $\begin{array}{l}\mathrm{I}-\mathrm{J}=1.47 \\
\mathrm{p}=0.002\end{array}$ & - & $\mathrm{X}$ & - \\
\hline$>60(1.44)$ & - & $\begin{array}{l}\mathrm{I}-\mathrm{J}=1.28 \\
\mathrm{p}=0.018\end{array}$ & - & - & $\mathrm{X}$ \\
\hline
\end{tabular}


Table 15. Results post-doc HSD Tukey test -declared engagement on the local level (by degree)

\begin{tabular}{c|cccc}
\hline \multirow{2}{*}{ MA (5.00) } & MA (5.00) & PhD (2.32) & Post-doc (2.43) & Professor (1.80) \\
\cline { 2 - 5 } & - & $\mathrm{I}-\mathrm{J}=2.67$ & $\mathrm{I}-\mathrm{J}=2.57$ & $\mathrm{I}-\mathrm{J}=3.20$ \\
$\mathrm{PhD}(2.32)$ & $\mathrm{p}=0.005$ & $\mathrm{p}=0.007$ & $\mathrm{p}=0.002$ \\
Post-doc (2.43) & $\begin{array}{l}\mathrm{I}-\mathrm{J}=2.67 \\
\mathrm{p}=0.005\end{array}$ & - & $\mathrm{X}$ & $\mathrm{X}$ \\
Professor (1.80) & $\begin{array}{l}\mathrm{I}-\mathrm{J}=2.57 \\
\mathrm{p}=0.007\end{array}$ & $\mathrm{X}$ & - & $\mathrm{X}$ \\
$\mathrm{I}-\mathrm{J}=3.20$ & $\mathrm{p}=0.002$ & $\mathrm{X}$ & $\mathrm{X}$ & - \\
\hline
\end{tabular}

